\title{
Chemoautotrophic growth of ammonia-oxidizing Thaumarchaeota enriched from a pelagic redox gradient in the Baltic Sea
}

\author{
Carlo Berg ${ }^{1+}$, Luisa Listmann ${ }^{1}$, Verona Vandieken ${ }^{1,2}$, Angela Vogts ${ }^{1}$ and Klaus Jürgens ${ }^{1 *}$ \\ Biological Oceanography, Leibniz Institute for Baltic Sea Research Warnemünde (IOW), Rostock, Germany \\ 2 Paleomicrobiology Group, Institute for Chemistry and Biology of the Marine Environment, Carl von Ossietzky University of Oldenburg, Oldenburg, Germany
}

Edited by:

Anton F. Post, Josephine Bay Paul Center for Comparative Molecular Biology and Evolution, USA

Reviewed by:

James T. Hollibaugh, University of Georgia, USA

Zongze Shao, State Oceanic

Administration, China

*Correspondence:

Klaus Jürgens, Biological

Oceanography, Leibniz Institute for

Baltic Sea Research Warnemünde

(IOW), Seestr. 15, 18119 Rostock,

Germany

e-mail: klaus.juergens@

io-warnemuende.de

${ }^{\dagger}$ Present address:

Carlo Berg, Science for Life Laboratory, Stockholm University,

Stockholm, Sweden
Ammonia-oxidizing archaea (AOA) are an important component of the planktonic community in aquatic habitats, linking nitrogen and carbon cycles through nitrification and carbon fixation. Therefore, measurements of these processes in culture-based experiments can provide insights into their contributions to energy conservation and biomass production by specific AOA. In this study, by enriching AOA from a brackish, oxygen-depleted water-column in the Landsort Deep, central Baltic Sea, we were able to investigate ammonium oxidation, chemoautotrophy, and growth in seawater batch experiments. The highly enriched culture consisted of up to $97 \%$ archaea, with maximal archaeal numbers of $2.9 \times 10^{7}$ cells $\mathrm{mL}^{-1}$. Phylogenetic analysis of the $16 \mathrm{~S}$ rRNA and ammonia monooxygenase subunit $\mathrm{A}(\mathrm{amo}) \mathrm{A})$ gene sequences revealed an affiliation with assemblages from low-salinity and freshwater habitats, with Candidatus Nitrosoarchaeum limnia as the closest relative. Growth correlated significantly with nitrite production, ammonium consumption, and $\mathrm{CO}_{2}$ fixation, which occurred at a ratio of 10 atoms $\mathrm{N}$ oxidized per 1 atom $\mathrm{C}$ fixed. According to the carbon balance, AOA biomass production can be entirely explained by chemoautotrophy. The cellular carbon content was estimated to be $9 \mathrm{fg} \mathrm{C}$ per cell. Single-cell-based ${ }^{13} \mathrm{C}$ and ${ }^{15} \mathrm{~N}$ labeling experiments and analysis by nano-scale secondary ion mass spectrometry provided further evidence that cellular carbon was derived from bicarbonate and that ammonium was taken up by the cells. Our study therefore revealed that growth by an AOA belonging to the genus Nitrosoarchaeum can be sustained largely by chemoautotrophy.

Keywords: ammonia-oxidizing archaea, Baltic Sea, chemoautotrophy, $\mathrm{CO}_{2}$-fixation, enrichment, Thaumarchaeota

\section{INTRODUCTION}

The aerobic oxidation of ammonia $\left(\mathrm{NH}_{3}\right)$ or ammonium $\left(\mathrm{NH}_{4}^{+}\right)$ to nitrite $\left(\mathrm{NO}_{2}^{-}\right)$is an essential step in the cycling of nitrogen and was long assumed to be performed exclusively by distinct members of Bacteria. This paradigm changed (Francis et al., 2007; Lam et al., 2009) following the discovery of the ammonia monooxygenase subunit A $(a m o A)$ gene among Archaea (Venter et al., 2004; Treusch et al., 2005) and the subsequent isolation of the first marine representative of the ammonia-oxidizing archaea (AOA), Candidatus Nitrosopumilus maritimus (Könneke et al., 2005). Molecular surveys inferring the presence of AOA via the detection of $a m o A$ recognized their global prevalence in many marine habitats (e.g., Francis et al., 2005). All known archaea possessing the amoA gene affiliate within the novel phylum Thaumarchaeota (Brochier-Armanet et al., 2008; Spang et al., 2010), formerly assigned to the Crenarchaeota. The global distribution and high abundances of AOA (Francis et al., 2005) point to their major impact on biogeochemical cycles. Cell-specific balances of carbon utilization and ammonia oxidation allow estimates of overall fluxes in specific ecosystems. In field studies, a correlation was determined between archaeal amoA transcripts and the occurrence of Thaumarchaeota (Caffrey et al., 2007; Beman et al., 2008). As deduced from the growth conditions of isolates (Könneke et al., 2005; Tourna et al., 2011), culture enrichments (e.g., Hatzenpichler et al., 2008; Jung et al., 2011; Matsutani et al., 2011; Santoro and Casciotti, 2011; French et al., 2012; Lebedeva et al., 2013), and the gene sets detected in AOA genomes (e.g., Hallam et al., 2006a,b; Walker et al., 2010; Blainey et al., 2011; Spang et al., 2012), ammonia oxidation serves to conserve energy and the fixation of inorganic carbon to generate biomass. Yet, variations have also been described, such as the utilization of urea (Hallam et al., 2006a,b; Alonso-Sáez et al., 2012) or the absence of ammonia oxidation despite the expression of amoA (Mußmann et al., 2011). Additionally, autotrophy as the sole carbon source for growth has been debated for AOA. In a study of wastewater treatment plants, no evidence of $\mathrm{CO}_{2}$ fixation by $\mathrm{AOA}$ was found, despite their abundance and active growth (Mußmann et al., 2011). Furthermore, the utilization of organic carbon by marine archaeal (Ouverney and Fuhrman, 2000) or thaumarchaeotal assemblages (Teira et al., 2006) as well as by AOA isolates was reported: for example, the growth of Nitrososphaera viennensis was substantially enhanced when pyruvate was provided as an 
additional organic carbon source (Tourna et al., 2011; Stieglmeier et al., 2014), and two recent isolates related to Ca. N. maritimus showed obligate mixotrophy, since their growth depended on the assimilation of organic carbon compounds (Qin et al., 2014).

Due to their chemolithoautotrophic lifestyle, in many ecosystems AOA are part of the organismal backbone involved in element transformations. Studies of the genomes of $\mathrm{Ca}$. Nitrosopumilus maritimus, Nitrososphaera viennensis, and $\mathrm{Ca}$. Nitrosoarchaeum limnia, revealed carbon fixation via a modified 3-hydroxypropionate/4-hydroxybutyrate cycle (3-HP/4-HB) (Berg et al., 2007; Walker et al., 2010; Blainey et al., 2011; Tourna et al., 2011). The use of this very cost-effective $\mathrm{CO}_{2}$ fixation pathway by AOA (Könneke et al., 2014) distinguishes them from autotrophic ammonia-oxidizing bacteria, which use the CalvinBenson-Basham cycle (e.g., Chain et al., 2003; Klotz et al., 2006). AOA capable of using the 3-HP/4-HB-cycle may also metabolize small organic substrates, as suggested by Hatzenpichler (2012). Despite the fact that most enriched or isolated Thaumarchaeota grow chemoautotrophically on inorganic media, the relationship between ammonia oxidation and chemoautotrophy has not been studied. Direct measurements of $\mathrm{CO}_{2}$ fixation by AOA are scarce and the fraction of AOA that live autotrophically is unknown for most environments.

Besides three previously reported marine AOA isolates (Könneke et al., 2005; Qin et al., 2014), AOA enrichment cultures from various sources have been established and investigated, e.g., from freshwater (French et al., 2012), estuarine sediments (Mosier et al., 2012), the ocean (Wuchter et al., 2006; Santoro and Casciotti, 2011), agricultural soil (Jung et al., 2011), and thermal habitats (Hatzenpichler et al., 2008), among others. These studies have contributed new details on the physiology, niche partitioning, and biogeochemistry of Thaumarchaeota. Because data on specific biogeochemical activities of AOA in natural environments are difficult to acquire, activity-based experiments with AOA enrichment cultures offer a suitable alternative approach.

In oxygen-depleted waters of the Baltic Sea, Thaumarchaeota account for up to one third of the total cell counts and thus constitute a substantial fraction of the microbial community (Labrenz et al., 2010; Berg et al., 2014). At the overlap of oxygen and ammonium gradients, AOA are the main catalyzers of ammonia oxidation (Berg et al., 2014). Moreover, they supply oxidized $\mathrm{N}$ for denitrification, a relevant N-loss process in the Baltic Sea nitrogen cycle, that is carried out in pelagic redox gradients mainly by chemoautotrophic epsilonproteobacteria (Grote et al., 2012).

In this study, we investigated the balances of chemoautotrophy and ammonium oxidation in an AOA enrichment culture obtained from the Landsort Deep redox gradient, central Baltic Sea. Our findings provide insights into the coupling between ammonium oxidation and carbon fixation in this enrichment and therefore on the relevance of chemoautotrophy for the generation of biomass by an AOA of the genus Nitrosoarchaeum.

\section{MATERIALS AND METHODS RETRIEVAL OF ENVIRONMENTAL SAMPLES, ENRICHMENT, AND CULTIVATION}

Water from the Baltic Sea Landsort Deep station TF284 $\left(58^{\circ}\right.$ $35.0183 \mathrm{~N}, 018^{\circ} 14.0795 \mathrm{E}$ ) was retrieved onboard the $R / V$ Heincke in November 2010. Samples were taken from the pelagic redox gradient at a depth of $90 \mathrm{~m}$, with salinity of 10.0 and where oxygen was depleted to $2.5 \mu \mathrm{mol} \mathrm{L}{ }^{-1}$, so that a high abundance of Thaumarchaeota can be expected (Labrenz et al., 2010; Berg et al., 2014). After sampling and during enrichment, the water was kept under oxic conditions and in the dark; $1 \mathrm{mmol} \mathrm{NH}_{4} \mathrm{Cl} \mathrm{L}^{-1}$ and $50 \mathrm{mg}$ streptomycin $\mathrm{L}^{-1}$ were added. The sample bottles were stored at room temperature with aerobic headspace and occasionally screened for $\mathrm{NO}_{2}^{-}$production according to the method described by Grasshoff et al. (1983). To select for the typically small thaumarchaeotal cells (diameter $<0.22 \mu \mathrm{m}$, Könneke et al., 2005; Labrenz et al., 2010), water from nitrite-positive bottles was filtered through $0.45-\mu \mathrm{m}$ syringe filters and the filtrate further incubated. Enrichments with continuous $\mathrm{NO}_{2}^{-}$production and increased archaeal cell numbers were inoculated into $0.1-\mu \mathrm{m}$ filtered seawater collected from Baltic Sea redox gradients and supplemented with $\mathrm{NH}_{4} \mathrm{Cl}$ and streptomycin, as described above, to further promote the growth of AOA. After approximately 1.5 years, with occasional transfers of $10-15 \%$ of the volume into $0.1-\mu \mathrm{m}$ filtered seawater, archaea numerically dominated the enrichments. A batch growth experiment was carried out, during which growth was monitored along with chemoautotrophy and ammonium oxidation. All batch enrichment cultures were kept in $1-\mathrm{L}$ or $2-\mathrm{L}$ bottles at $22^{\circ} \mathrm{C}$ in incubation chambers and in the dark. Concentrations of ammonium and nitrite were determined according to the methods of Grasshoff et al. (1983). Ammonium was measured directly after sampling; nitrite samples were filtered through $0.2-\mu \mathrm{m}$ filters and stored at $-20^{\circ} \mathrm{C}$ until analysis. All batch cultures were inoculated from the same initial enrichment.

\section{CELl QUANTIFICATION}

Depending on the cell density, $0.1-4 \mathrm{~mL}$ subsamples of the enrichment cultures were fixed for $2-6 \mathrm{~h}$ with particle-free formaldehyde ( $2 \%$ final concentration) and subsequently filtered on $0.2-\mu \mathrm{m}$ polycarbonate filters (Whatman, $25 \mathrm{~mm}$ diameter). Archaeal or bacterial cells on the filter slices were specifically hybridized via catalyzed reporter deposition fluorescence in situ hybridization (CARD-FISH) according to Pernthaler et al. (2002), using either the Arc915 probe targeting archaea (Stahl and Amann, 1991) or the EUB338/EUB338II-III probe mix targeting bacteria (Amann et al., 1990; Daims et al., 1999). Cells on the hybridized filters were counter-stained with 4',6-diamidino2-phenylindol (DAPI) in Vectashield mounting medium (Vector Labs, Burlingame, California, USA). Ten microscopic fields were randomly selected to count DAPI-stained and specifically hybridized cells using a Zeiss Axioskop 2 mot plus epifluorescence microscope (Zeiss, Oberkochen, Germany). For three of the enrichment cultures (A, B, and C), filters were prepared and analyzed in triplicate; cells that were hybridized during CARD-FISH were counted on slices from one filter.

\section{$\mathrm{CO}_{2}$ FIXATION RATES}

Subsamples of $2-4 \mathrm{~mL}$ were taken from the batch cultures and incubated in triplicate together with a killed control (fixed with $2 \%$ formaldehyde) for $6-24 \mathrm{~h}$ after the addition of $0.56-1.85 \mathrm{MBq}$ of $\mathrm{NaH}^{14} \mathrm{CO}_{3}$ (Hartmann Analytic $\mathrm{GmbH}$, Germany), depending on the cell density. The incubations were stopped by filtration 
onto $0.2-\mu \mathrm{m}$ polycarbonate (Whatman, $25 \mathrm{~mm}$ diameter) filters. Prior to filtration, $50 \mu \mathrm{L}$ were withdrawn to determine the total radioactivity added to each vial. The filters were exposed to $\mathrm{HCl}$ fumes for $0.5-2 \mathrm{~h}$ and then transferred into $4 \mathrm{~mL}$ of LumaSafe scintillation cocktail (PerkinElmer). Total- and filter${ }^{14} \mathrm{C}$ disintegrations per minute were analyzed with a PerkinElmer Tri-Carb 2800R liquid scintillation analyzer. $\mathrm{CO}_{2}$ fixation rates were derived from the fraction of ${ }^{14} \mathrm{C}$ incorporated in relation to the total activity added and taking into account the dissolved inorganic carbon concentration of $2 \mathrm{mmol} \mathrm{L}^{-1}$ that is characteristic of Baltic Sea redox gradients (Grote et al., 2008; Berg et al., 2014). $\mathrm{CO}_{2}$ fixation rates were calculated as follows:

$$
\mathrm{CO}_{2} \text { fixation }=\frac{\frac{d p m_{f}-d p m_{d}}{d p m_{l}} \times D I C}{t}
$$

where $t$ is the incubation time; $d p m_{f}$, the filter disintegrations per minute; $d p m_{d}$, the dpm counts on filters of the killed control; $d p m_{l}$, the dpm counts in the liquid sample; and DIC, the ambient concentration of dissolved inorganic carbon.

Mean $\mathrm{CO}_{2}$ fixation rates and the increase in cell numbers during the exponential growth phase (from $t_{1}$ to $t_{2}$ ) between days 19 and 32 (enrichments A, B, and C) and days 32 and 54 (enrichment E) were considered in calculating the carbon content of one cell as follows:

$$
C_{\text {content }}=\frac{\frac{\left[\mathrm{CO}_{2} \text { fixation rate }\right]_{t_{2}}+\left[\mathrm{CO}_{2} \text { fixation rate }\right]_{t_{1}}}{2} \times\left(t_{2}-t_{1}\right)}{\left[\text { cells } m L^{-1}\right]_{t_{2}}-\left[\text { cells } m L^{-1}\right]_{t_{1}}}
$$

To determine the accumulated amount of fixed $\mathrm{CO}_{2}$, the fixation rates were multiplied by the number of days until the next $\mathrm{CO}_{2}$ fixation rate measurement. These intervals were then cumulatively added for the specific time points of the $\mathrm{CO}_{2}$ fixation rate measurements. A correlation was tested by linear bivariate regression using the PAST software package v3.0 (Hammer et al., 2001).

\section{UPTAKE OF ${ }^{13} \mathrm{C}$-BICARBONATE AND ${ }^{15} \mathrm{~N}$-AMMONIUM AND NANOSIMS IMAGING}

Enrichment culture $\mathrm{G}$ was amended with $2 \mathrm{mmol} \mathrm{NaH}^{13} \mathrm{CO}_{3}$ $\mathrm{L}^{-1}\left(99 \%{ }^{13} \mathrm{C}\right.$, Cambridge Isotope Laboratories, Massachusetts, USA) directly after inoculation; $58 \mu \mathrm{mol}{ }^{15} \mathrm{NH}_{4} \mathrm{Cl} \mathrm{L}^{-1}$ (99\% ${ }^{15} \mathrm{~N}$, Cambridge Isotope Laboratories, Tewksbury, Massachusetts, USA) was added during the exponential growth phase (on day 40). For single-cell analysis by nano-scale secondary ion mass spectrometry (NanoSIMS) (e.g., Musat et al., 2012), samples from the enrichment were taken at several time points and processed using the same procedure described for CARD-FISH except that they were filtered onto gold-coated $0.2-\mu \mathrm{m}$ polycarbonate filters. The filter surface was gold-sputter-coated with an Agar sputter coater (model 108) for $120 \mathrm{~s}$, resulting in a $20-40-\mathrm{nm}$ thin layer of gold. Incorporation of the label into single cells was assessed using a Cameca NanoSIMS 50L, by measuring the secondary ions emitted in response to sputtering selected areas of the filter surface by a $\mathrm{Cs}^{+}$primary ion beam. The primary ion beam current was $2 \mathrm{pA}$, with scanning parameters of $256 \times 256$ pixels for areas of $20 \times 20-30 \times 30 \mu \mathrm{m}$, with a dwell time of $1 \mu \mathrm{s}$ per pixel. The mass resolving power was adjusted to suppress interferences at all masses. Data of the secondary ion counts were analyzed using the MATLAB R2011b (The MathWorks, USA) based Look@NanoSIMS software (Polerecky et al., 2012). Thus, 30-60 planes were aligned and included in the analysis; regions of interest were defined using the biomass signal based on the ${ }^{12} \mathrm{C}^{14} \mathrm{~N}$ - counts. Ratios of ${ }^{13} \mathrm{C} /{ }^{12} \mathrm{C}$ were derived from the secondary ion counts of ${ }^{13} \mathrm{C}^{-}$and ${ }^{12} \mathrm{C}^{-}$, respectively, to determine ${ }^{13} \mathrm{C}$ enrichment. Cellular ${ }^{15} \mathrm{~N}$ uptake was determined by calculating the ratio ${ }^{15} \mathrm{~N}^{12} \mathrm{C}-/{ }^{14} \mathrm{~N}^{12} \mathrm{C}$-.

\section{DNA-EXTRACTION AND PHYLOGENETIC ANALYSIS OF THE 16S rRNA AND amoA GENES}

Samples were taken on day 54, i.e., during the late exponential phase, from enrichment cultures $D-G$ and filtered on $0.2-\mu \mathrm{m}$ GVWP filters (Millipore). DNA was extracted as described in Weinbauer et al. (2002). DNA of the nearly full-length 16S rRNA gene was PCR-amplified using the Fermentas taq polymerase and the primer pairs Arch21f/1492r (Lane, 1991; DeLong, 1992) for Archaea and 27f/1492r (Lane, 1991) for Bacteria. The archaeal amoA primer pairs were Arch-amoAF/Arch-amoAR (Francis et al., 2005); the beta- and gammaproteobacterial amoA primers were $a m o A-1 \mathrm{~F} / 2 \mathrm{R}$ and $a m o A-3 \mathrm{~F} / 4 \mathrm{R}$, respectively (Purkhold et al., 2000). PCR products were purified using the Agencourt AMPure kit XP (Beckman Coulter, Krefeld, Germany) according to the manufacturer's instructions. Both the $16 \mathrm{~S}$ rRNA gene and the amoA gene amplicons were cloned with the StrataClone PCR cloning kit (Agilent, Karlsruhe, Germany) as described by the manufacturer and sequenced by LGC Genomics (Berlin, Germany). The sequences were quality-revised with DNAStar SeqMan II v5.06 and forward and reverse sequences were assembled into a contig. Chimeric sequences were detected using DECIPHER (Wright et al., 2012). Phylogenetic analysis was conducted using the ARB 5.1 software package (Ludwig et al., 2004). The 16S rRNA gene sequences were aligned with the online SILVA incremental aligner (SINA) v1.2.11 (Pruesse et al., 2012), then imported into ARB and inspected for alignment errors. Translated $a m o A$ protein sequences were aligned using the amoA ARB database provided by Pester et al. (2012). The 16S rRNA gene phylogenetic tree was constructed with the Phylip neighbor-joining algorithm, Jukes-Cantor correction, and using the ssuref:archaea filter provided in the SILVA SSU Ref NR 99 ARB database (Quast et al., 2013). The amoA neighbor-joining tree was generated based on the protein alignment, using Phylip with a Fitch model and $\mathrm{Ca}$. N. maritimus SCM1 as a filter. The amoA gene and 16S rRNA gene sequences were deposited in the European Nucleotide Archive under the accession numbers LN590601-LN590650 and LN590651-LN590669, respectively.

\section{RESULTS}

\section{ENRICHMENT OF AMMONIA-OXIDIZING ARCHAEA}

Samples obtained from oxygen-depleted waters of the Baltic Sea were incubated for 1.5 years under conditions promoting the growth of AOA and resulted in cultures highly enriched in AOA (Figure 1). AOA enrichment was evident from nitrite production, the consumption of ammonium, and the concurrent increase in archaeal cell numbers (Figure 2). CARD-FISH for 
archaea revealed that cells similar in size and morphology to $\mathrm{Ca}$. N. maritimus (Könneke et al., 2005; Figure 1) dominated the cultures.

In a batch growth experiment at $22^{\circ} \mathrm{C}$, total cell numbers during exponential growth reached a maximum of $3.1 \times 10^{7}$ cells $\mathrm{mL}^{-1}$, with archaeal cells comprising 93-97\%, as determined by CARD-FISH (Figure 2), and bacterial cells, identified with the probes EUB338I-III on day 43, 5-10\% (cultures A, B, and C). After a lag phase of 19 days, the archaeal cells grew exponentially, with a generation time of 4.5 days (Table 1). Ammonium consumption during exponential growth accounted for an oxidation rate of $12.81 \pm 0.80 \mu \mathrm{mol} \mathrm{NH}_{4}^{+} \mathrm{L}^{-1} \mathrm{~d}^{-1}$ and was accompanied by
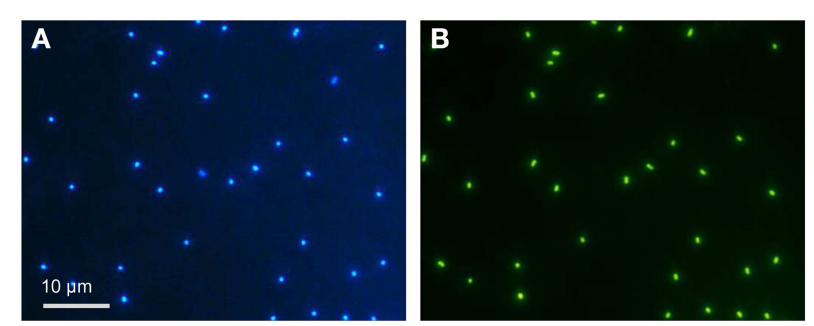

FIGURE 1 | Epifluorescence microscopy of representative cells from enrichment culture $\mathbf{B}$ on day 1. The cells were stained with DAPI (A) or hybridized with the archaea-specific probe $\operatorname{Arc915}$ (B) and then analyzed by CARD-FISH. Same field of view; the scale bar represents $10 \mu \mathrm{m}$. the increase in archaeal cell numbers and the near-stoichiometric accumulation of nitrite at a rate of $9.42 \pm 1.53 \mu \mathrm{mol} \mathrm{L}^{-1} \mathrm{~d}^{-1}$. Culture $G$ showed similar properties but with a longer generation time (Table 1 ): total cell numbers reached $5.2 \times 10^{7}$ cells $\mathrm{mL}^{-1}$ and ammonium was completely consumed at a rate of $11.55 \mu \mathrm{mol} \mathrm{NH}+\mathrm{L}^{-1} \mathrm{~d}^{-1}$, comparable to that by cultures A$\mathrm{C}$ (Figure 3). Enrichment cultures D and F (Figure A2) grew more slowly and less continuously, reaching maximum total cell abundances of $1.5 \times 10^{7}$ cells $\mathrm{mL}^{-1}$. The growth of enrichment culture E (Figure A2) was similar to that of cultures A-C and G.

\section{$\mathrm{CO}_{2}$ FIXATION}

$\mathrm{CO}_{2}$ fixation rates in cultures $\mathrm{A}, \mathrm{B}$, and $\mathrm{C}$ reached $161 \mathrm{nmol}$ $\mathrm{L}^{-1} \mathrm{~d}^{-1}$ (Figure 2B) during the lag phase and, together with cell numbers and ammonium consumption, increased substantially with the onset of the exponential growth phase. Bulk

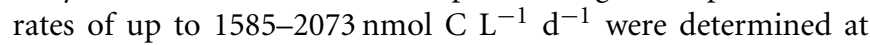

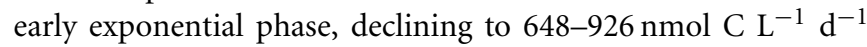
during early stationary phase. Calculated archaeal-cell-specific $\mathrm{CO}_{2}$ fixation rates were highest on day 23, at $0.2 \pm 0.06$ fmol C cell ${ }^{-1}$ (Table 1 and Figure 4). Determination of the cumulative amount of $\mathrm{CO}_{2}$ fixed over time showed that the total amount of incorporated $\mathrm{C}$ correlated with the increase in Arc915-hybridized cell counts (e.g., culture A: $r^{2}=0.992$, $p=2.4 \times 10^{-5}$; Figure $\mathrm{A} 1$ ). Based on a comparison of $\mathrm{CO}_{2}$ fixation and ammonium oxidation rates in cultures $\mathrm{A}-\mathrm{C}$ during
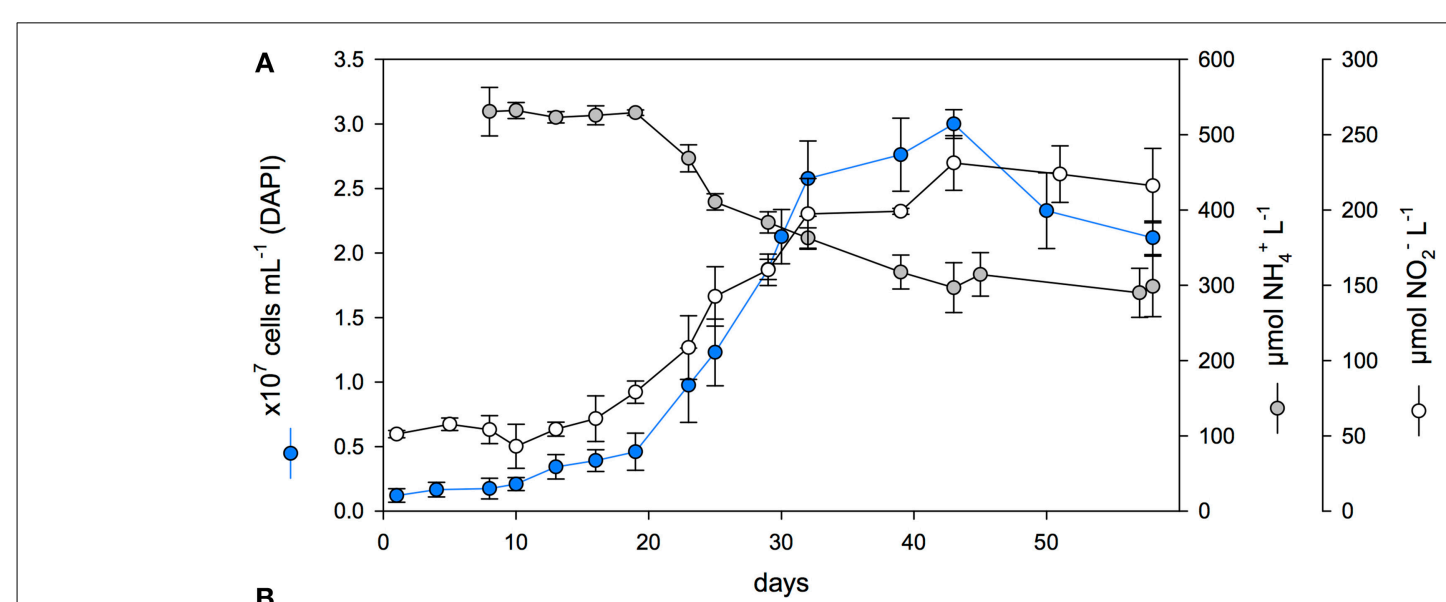

B
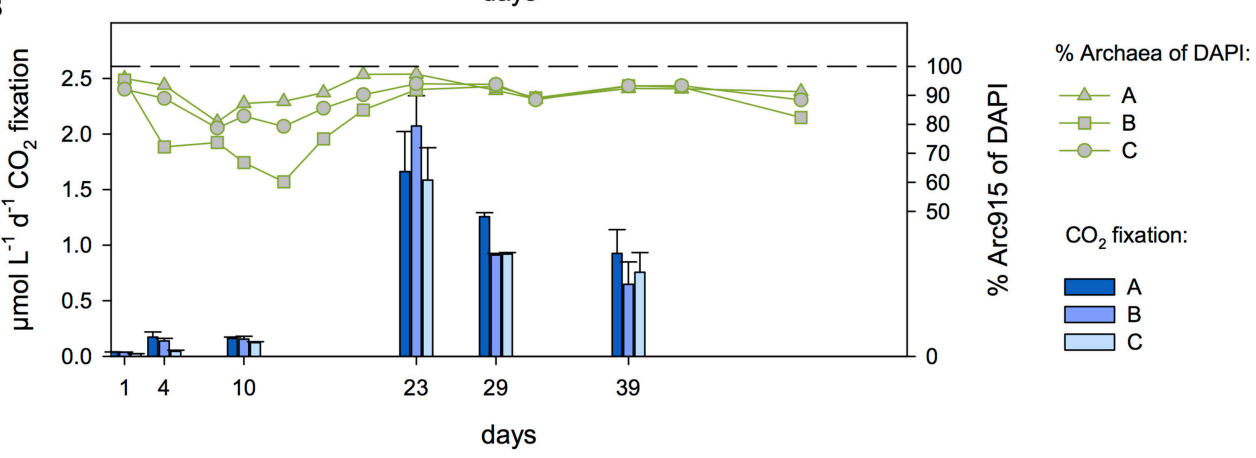

FIGURE 2 | Cell numbers, ammonium and nitrite concentrations (A) as well as $\mathrm{CO}_{2}$ fixation rates, and the archaeal fraction (B) in triplicate enrichment cultures (termed A, B and C). Error bars show the standard deviations of cell counts and nitrite and ammonium concentrations from cultures grown in triplicate. 
Table 1 | Growth characteristics and balances during the exponential phase of enrichment cultures grown on natural $0.1-\mu \mathrm{m}$ filtered seawater.

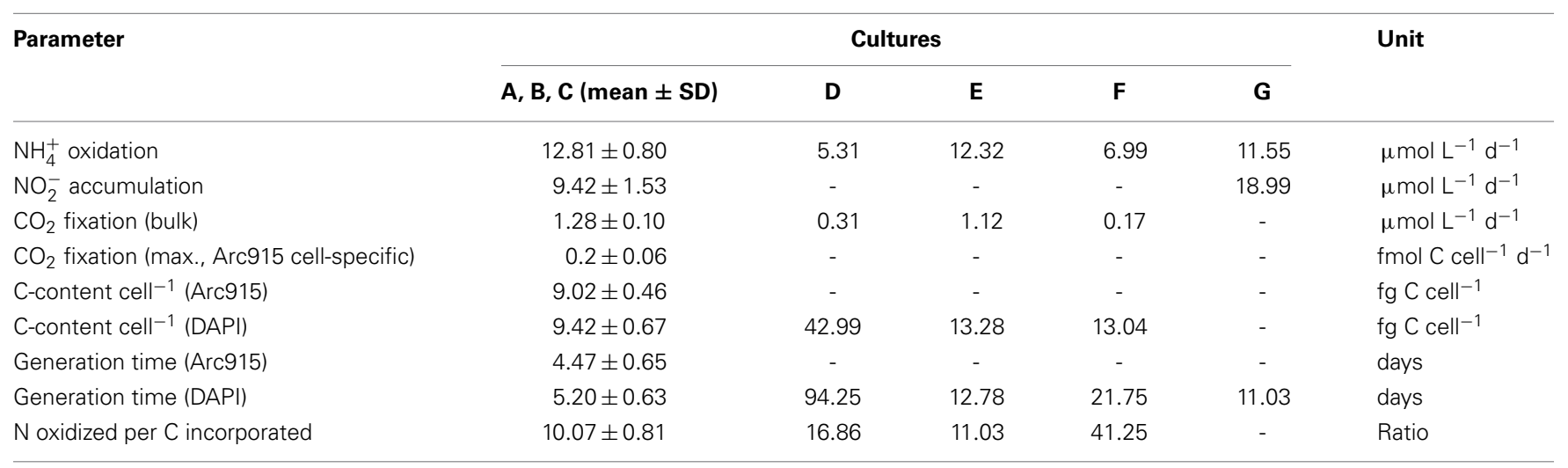

Ammonium oxidation rates were determined by measuring the decrease in $\mathrm{NH}_{4}^{+}$concentrations. -, not determined; SD, standard deviation of triplicate cultures.

exponential growth, one atom $\mathrm{C}$ was fixed per 10 atoms $\mathrm{N}$ oxidized (Table 1).

\section{CELLULAR UPTAKE OF ${ }^{13}$ C-BICARBONATE AND ${ }^{15} \mathrm{~N}$-AMMONIUM}

Enrichment culture $G$ was amended after inoculation with $2 \mathrm{mmol}$ of ${ }^{13} \mathrm{C}$-labeled bicarbonate $\mathrm{L}^{-1}$ (Figure 3A), corresponding to $50 \%{ }^{13} \mathrm{C}$-labeled bicarbonate, in addition to an ambient concentration of $2 \mathrm{mmol} \mathrm{L}^{-1}$ bicarbonate in the seawater-based medium. During the lag phase, the enrichment of ${ }^{13} \mathrm{C}$ in individual cells inspected via NanoSIMS increased above the natural ratio of 0.011 (Nier, 1950; International Atomic Energy Agency, IAEA) to 0.2 (Figure 3B and Figure A3). During exponential growth, on days 42 and 47 , the ratio of ${ }^{13} \mathrm{C} /{ }^{12} \mathrm{C}$ increased up to 0.5 . Among all cells investigated $(n=268)$ the ratios varied; on days 42 and 47 , mean ${ }^{13} \mathrm{C}$ enrichment was $0.22 \pm 0.09$ and $0.14 \pm 0.09$, respectively. NanoSIMS image analysis showed that the labeled cells were analogous in size and morphology to the Arc915-hybridized cells detected via epifluorescence microscopy (Figure 1). Nearly all of the investigated cells were ${ }^{13} \mathrm{C}$-enriched, with enrichment levels above the background values of the polycarbonate filters, the unlabeled cells of the control, and the natural ${ }^{13} \mathrm{C} /{ }^{12} \mathrm{C}$ ratio.

On day 40, ${ }^{15} \mathrm{~N}$-labeled ammonium was added, corresponding to $22 \%{ }^{15} \mathrm{~N}$ labeling of the ammonium pool on that day. Subsequently, the ratio of ${ }^{15} \mathrm{~N}$ vs. ${ }^{14} \mathrm{~N}$ in the cells was 0.04 on day 42 and as high as 0.19 on day 47, with means of $0.02 \pm 0.006$ and $0.12 \pm 0.04$, respectively (Figure 3D and Figure A4). These ratios were considerably higher than the natural ratio of 0.004 (Nier, 1950).

\section{PHYLOGENETIC AFFILIATION}

Amplification of the bacterial and archaeal 16S rRNA genes from DNA extracts of the enrichment cultures yielded products only for Archaea. All $16 \mathrm{~S}$ rRNA gene sequences $(n=19)$ thus obtained fell within the Nitrosopumilus cluster and were closely related to each other. The closest phylogenetic relative was Ca. Nitrosoarchaeum limnia SFB1 (NZ_CM001158.1), with 98.8-99.9\% 16S rRNA gene sequence identity (Figure 5A). No beta- or gammaproteobacterial amo $A$ gene sequences were amplified, whereas all archaeal $a m o A$ gene sequences $(n=50)$ were affiliated with a putative low-salinity group (Figure 5B; Blainey et al., 2011). With respect to their amoA gene sequences, the enrichment had 99.4-99.7\% sequence identity with $C a$. N. limnia SFB1 (NZ_CM001158.1).

\section{DISCUSSION}

Ammonia-oxidizing Thaumarchaeota may be among the most relevant chemolithoautotrophs in aquatic habitats. Our enrichment of AOA (up to 97\% purity, Figures 1, 2) of the genus Nitrosoarchaeum showed that in seawater-based medium inorganic carbon fixation was sufficient to generate all cellular carbon. Ammonium utilization was ten-fold higher than dark carbon fixation, providing a relationship between these two processes, which can be carried out by most AOA. Phylogenetically, the enrichment was determined to fall within a putative low-salinity and freshwater group, concurrent with its environmental origin and the intermediate salinities of Baltic Sea redox gradients.

\section{AUTOTROPHY AND CARBON CONTENT PER CELL}

Growth of the AOA enrichment was accompanied by $\mathrm{CO}_{2}$ fixation activity, which substantially increased with the onset of the exponential growth phase (Figure 2). Thus, the major fraction of $\mathrm{CO}_{2}$ fixation can be attributed to archaeal growth; only minimal $\mathrm{CO}_{2}$ fixation may have been carried out by for example nitriteoxidizing bacteria, as the presence of streptomycin suppressed bacterial activities, archaea were highly enriched and nitrite accumulated near-stoichiometrically relative to ammonium oxidation. By relating the amount of incorporated inorganic carbon to the increase in archaeal cell numbers during exponential phase we calculated an average of $9.02 \mathrm{fg}$ of chemoautotrophy-derived carbon per newly produced cell (Table 1). This amount is comparable to the $8.39 \mathrm{fg} \mathrm{C}$ cell $^{-1}$ reported for autotrophic archaea in the deep Atlantic Ocean (Herndl et al., 2005). By contrast, the mean carbon content of planktonic prokaryotes is about $20 \mathrm{fg} \mathrm{C}$ cell $^{-1}$ (Lee and Fuhrman, 1987). However, due to the small cell size of AOA, lower carbon content is expected. Moreover, it suggests that $\mathrm{CO}_{2}$ fixation provided the major part of carbon for the production of an archaeal cell, while incorporation of organic carbon may still have occurred, however, at a smaller extent. Notably, this relationship may vary in environmental AOA populations. 


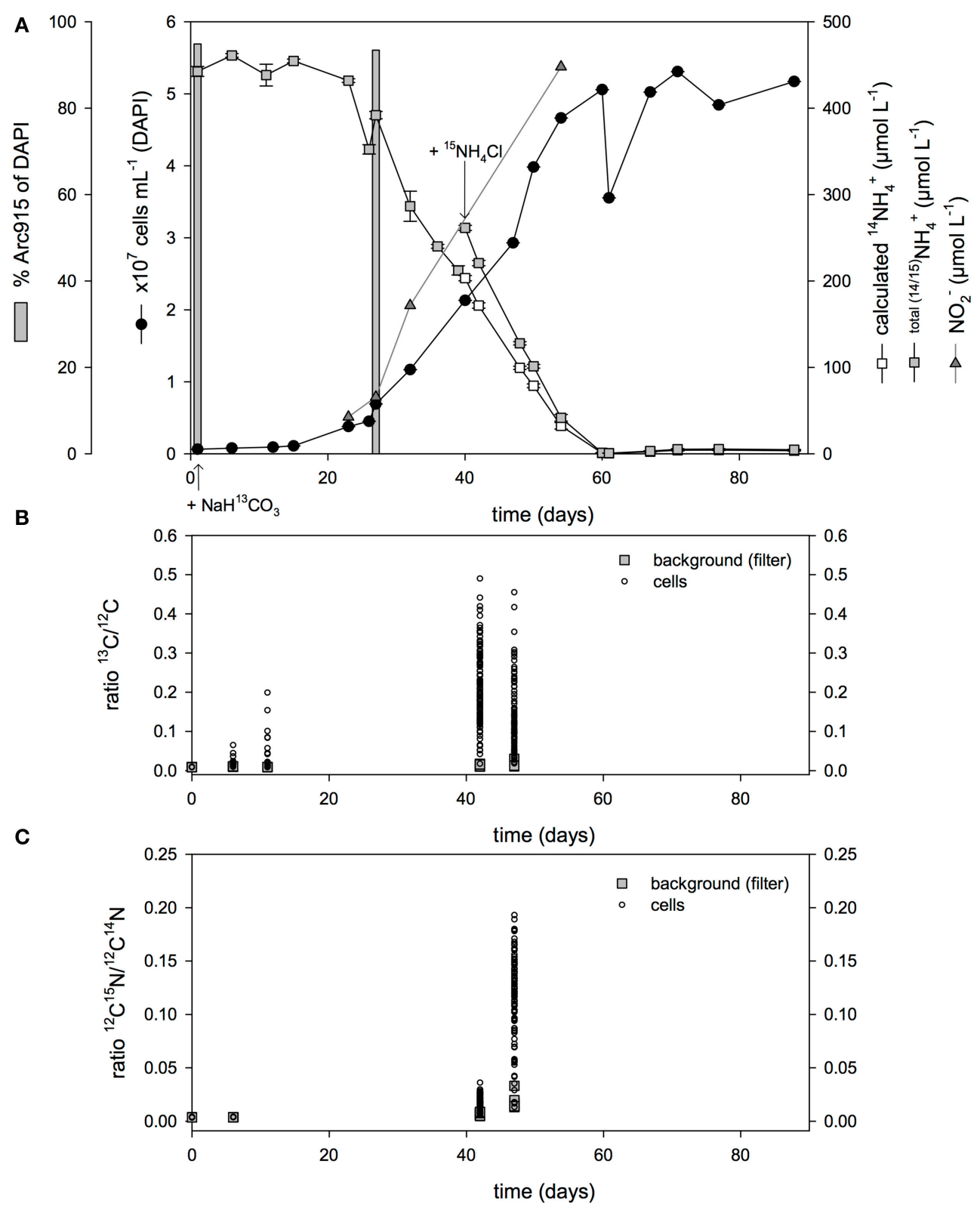

FIGURE 3 | (A) Growth curve of enrichment culture G, showing ammonium consumption, total cell numbers, and the fraction of archaeal cells.

${ }^{15} \mathrm{~N}$-labeled ammonium was added on day 40 . The combined ${ }^{14} \mathrm{NH}_{4}^{+}$and ${ }^{15} \mathrm{NH}_{4}^{+}$concentration is plotted together with the calculated concentration of

The maximal mean cell-specific $\mathrm{CO}_{2}$ fixation rate of $0.2 \pm 0.06$ fmol C cell ${ }^{-1}$ day $^{-1}$ (Figure 4) is higher than the rate calculated for marine archaea in the North Atlantic by Herndl et al. (2005) or Varela et al. (2011), who reported maximum rates of 0.014 and 0.1 fmol C cell ${ }^{-1}$ day $^{-1}$, respectively. These discrepancies may reflect the differences in physicochemical parameters, such as temperature or substrate availability or competition for substrates in natural environments compared to the growth conditions of the enrichment cultures.

Ideally, our calculations would be complemented by measurements of the particulate organic carbon (POC) content
${ }^{14} \mathrm{NH}_{4}^{+}$based on the percentage of labeling. Ratios of ${ }^{13} \mathrm{C}$ vs. ${ }^{12} \mathrm{C}(\mathbf{B})$ and ${ }^{15} \mathrm{~N}$ vs. ${ }^{14} \mathrm{~N}$ (C) enrichment in single cells was determined using NanoSIMS. Error bars show the standard deviation among triplicate samples. The data point of day 0 corresponds to unlabeled cells from enrichment $\mathrm{E}$.

in the enrichment cultures, but the low cell concentration and the small cell size did not yield sufficient biomass to allow conventional POC measurements. Attempts to filter the cells onto glass-fiber GF/F filters were not successful because most of the cells passed through them. However, the amount of incorporated carbon that accumulated, based on $\mathrm{CO}_{2}$ fixation rates (Figure A1), correlated with the increase in archaeal cell counts during batch growth, likewise suggesting that growth is mainly based on chemoautotrophy. Additionally, NanoSIMS analyses of single cells revealed that, until the exponential phase, up to $50 \%$ of the cellular ${ }^{13} \mathrm{C}$ carbon originated from labeled bicarbonate 
(Figures 3B,C), which reflects the fraction of ${ }^{13} \mathrm{C}$-labeled bicarbonate present in the medium. Although the cells analyzed by NanoSIMS were not re-identified by FISH, the dominance of archaea in the enrichment culture (Figure 3A) implies a high

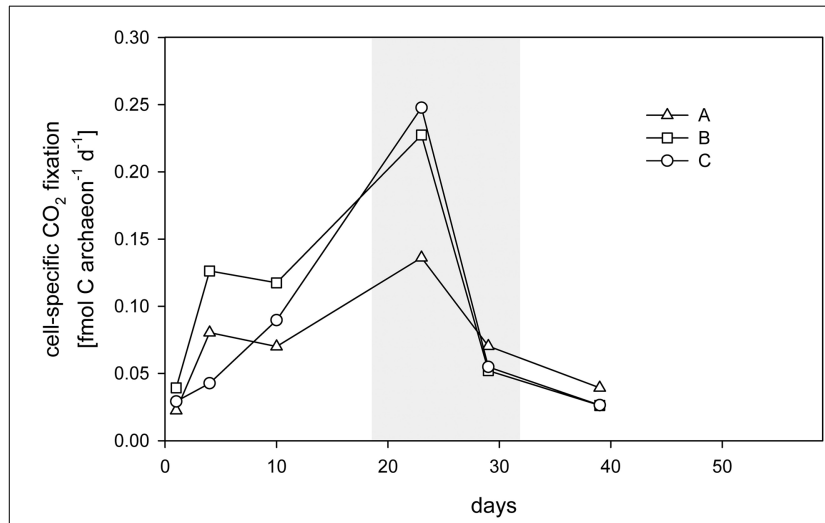

FIGURE 4 | Cell-specific $\mathrm{CO}_{2}$ fixation rates calculated from archaeal cell numbers and bulk $\mathrm{CO}_{2}$ fixation rates during the growth of enrichment cultures A, B, and $\mathbf{C}$. The exponential phase is shown in gray. probability that the investigated cells were AOA. The enrichment cultures were also susceptible to the archaea-specific biosynthesis inhibitor $N^{1}$-guanyl-1,7-diaminoheptane $\left(\mathrm{GC}_{7}\right)$ (Jansson et al., 2000), which led to a substantial decrease in $\mathrm{CO}_{2}$ fixation activity (Berg et al., 2014). Taken together, our data show that the generation of the major portion of archaeal biomass in the Nitrosoarchaeum enrichment relied on chemoautotrophy. Yet, our approach does not exclude the additional incorporation of small amounts of organic compounds, thus mixotrophic growth, since natural seawater is not free of dissolved organic carbon. For example, $N$. viennensis and the mixotrophic strains HCA1 and PS0, which are related to $\mathrm{Ca}$. N. maritimus SCM1, require pyruvate (Tourna et al., 2011) and $\alpha$-ketoglutaric acid (Qin et al., 2014), respectively. Nonetheless, our results underline the potential role of AOA in the carbon cycle, and their presence may imply preceding contributions to planktonic biomass via chemoautotrophy, especially considering the worldwide distribution of AOA (Francis et al., 2005), presumably dominating the large fraction of pelagic archaea in the dark ocean (Karner et al., 2001).

The shortest generation time in our enrichment was 4.5 days (Table 1), which is substantially longer than the $21-26 \mathrm{~h}$ (at $28^{\circ} \mathrm{C}$ ) reported for $\mathrm{Ca}$. Nitrosopumilus maritimus SCM1
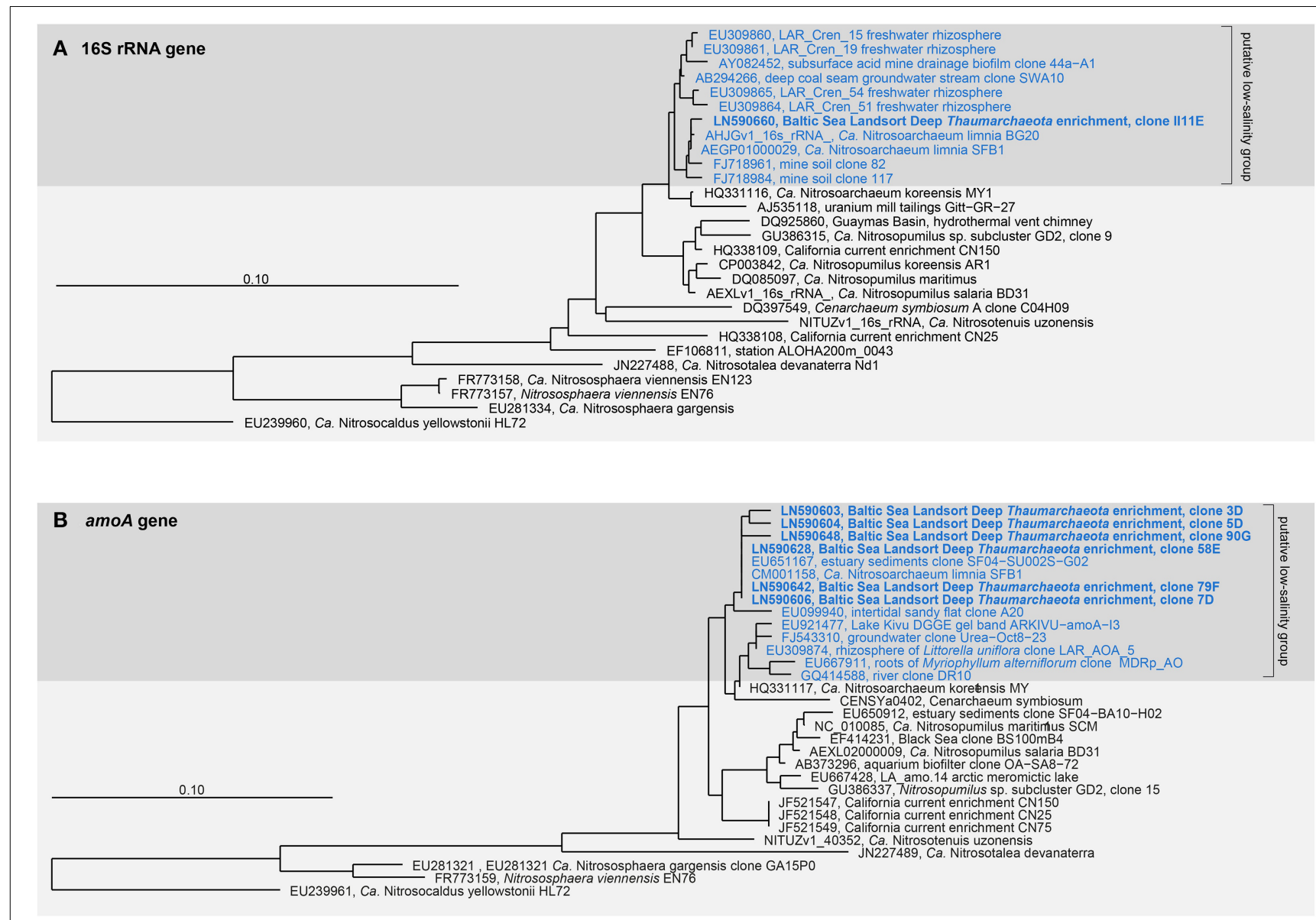

FIGURE 5 | Neighbor-joining trees showing the phylogenetic placement of the enrichment based on the cloned, nearly full-length 16S rRNA gene (A) and $\mathbf{a m o A}$ gene (B) sequences. The scale bar represents 10 iterations per 100 nucleotides (A) or amino acids (B). 
(Könneke et al., 2005; Martens-Habbena et al., 2009) or the $45 \mathrm{~h}$ (at $37^{\circ} \mathrm{C}$ ) of Nitrososphaera viennensis (Tourna et al., 2011) but comparable to the $4-4.6$ days (at $22^{\circ} \mathrm{C}$ ) determined in AOA enrichment cultures of the California Current that were grown in natural seawater-based medium (Santoro and Casciotti, 2011) and somewhat slower than the 3.4 days of the closest relative, $\mathrm{Ca}$. Nitrosoarchaeum limnia SFB1, grown at $22^{\circ} \mathrm{C}$ (Mosier et al., 2012). These differences may be the result of variations in media composition and cultivation temperatures, with faster growth promoted by warmer conditions. Clearly, the conditions used to obtain the enrichment cultures were different from the natural environment of the Baltic Sea redox gradients, where temperatures in the suboxic zone are year-round $5-7^{\circ} \mathrm{C}$. In the latter setting, growth is expected to be slower and may be limited by substrate availability, as maximum in situ ammonium oxidation rates are at least 15-fold lower (122-884 $\left.\mathrm{nmol} \mathrm{N} \mathrm{L}^{-1} \mathrm{~d}^{-1}\right)$ (Berg et al., 2014).

\section{COUPLING BETWEEN AMMONIA OXIDATION AND $\mathrm{CO}_{2}$ FIXATION}

In the coupling between nitrogen and carbon cycles, AOA play a crucial role. Their high substrate affinity for ammonia (MartensHabbena et al., 2009) may explain their occurrence in areas of low ammonium concentrations in the open ocean (reviewed by Erguder et al., 2009) and thus their broad distribution. Therefore, the availability of ammonia likely limits biomass production by AOA. In our study, ammonium oxidation and inorganic carbon fixation occurred at a ratio of $10 \mathrm{~N}$ oxidized per $1 \mathrm{C}$ incorporated (Table 1), if considering the energetically most efficient ratio (Table 1). To what extent this ratio may vary in natural populations for individual cells remains to be determined. However, it is in line with the 10:1 ratio previously discussed for nitrifiers (Tijhuis et al., 1993; Wuchter et al., 2006; Middelburg, 2011) and also comparable to the bulk nitrification and $\mathrm{CO}_{2}$ fixation rates determined in the central Baltic Sea (Berg et al., 2014): In the pelagic redox zone, where the gradients of oxygen and ammonium overlap and Thaumarchaeota are present in high numbers, nitrification rates (122-884 $\mathrm{nmol} \mathrm{N} \mathrm{L}^{-1} \mathrm{~d}^{-1}$ ) are approximately one order of magnitude higher than those of $\mathrm{CO}_{2}$ fixation $\left(19-58 \mathrm{nmol} \mathrm{C} \mathrm{L} \mathrm{L}^{-1} \mathrm{~d}^{-1}\right)$. This suggests that $\mathrm{CO}_{2}$ fixation in oxygen-deficient waters of the Baltic Sea is largely mediated by AOA, since other chemoautotrophic microorganisms, such as the gammaproteobacterial SUP05 (Glaubitz et al., 2013) and epsilonproteobacterial Sulfurimonas sp., reside and fix $\mathrm{CO}_{2}$ in deeper waters of the Baltic redox gradients, mainly around the oxic-anoxic interface and below (Grote et al., 2008).

\section{PHYLOGENETIC AFFILIATION WITH A PUTATIVE LOW-SALINITY GROUP}

Based on both 16S rRNA gene and amoA gene sequences, our Baltic Sea enrichment affiliates most closely with $C a$. Nitrosoarchaeum limnia (Figure 5) whereas 16S rRNA gene and $a m o A$ gene sequence identities to the thaumarchaeotal subcluster GD2, which is abundant in the Baltic Sea redox gradients (Labrenz et al., 2010), account for 94.1-98.0\% and 89.7-90.1\%, respectively.

Many Thaumarchaeota sequences recovered from similar habitats cluster in specific groups, indicating that niche partitioning is also reflected in amoA sequence diversity. A putative "low-salinity group" comprising sequences collected from streams, estuaries, and groundwater habitats was proposed by Blainey et al. (2011) and by Biller et al. (2012). The salinities characteristic of brackish pelagic redox gradients in the central Baltic Sea are in the range of 6-11 (Labrenz et al., 2007). Sequences recovered from our enrichment culture had 98.8-99.9\% 16S rRNA gene sequence identity with $\mathrm{Ca}$. Nitrosoarchaeum limnia SFB1 (Blainey et al., 2011), which originated from low-salinity (7.9) sediments of San Francisco Bay (Mosier et al., 2012). Although the two lowsalinity habitats are geographically far apart, the sequence identity between $C a$. N. limnia SFB1 and our enrichment is remarkably high for both the 16S rRNA and the amoA genes. Bouskill et al. (2012) argued that the geochemical properties of a habitat strongly determine the distribution of phylogenetic groups of ammonia oxidizers. This conclusion gained support from a comprehensive analysis of $a m o A$ sequences from aquatic habitats, in which Biller et al. (2012) found that salinity, among other parameters, determined the distribution of niche-specific amo $A$ sequence types. Genome sequencing of the enrichment may reveal physiological differences with $C a$. N. limnia SFB1, as even closely related AOA can inhabit strikingly different ecological niches (Qin et al., 2014).

Our growth experiment with a Baltic Sea AOA enrichment culture extends current knowledge on chemoautotrophic AOA by providing direct evidence that the biomass needed for cell growth is largely generated by the fixation of inorganic carbon. Furthermore, we were able to relate ammonium oxidation to $\mathrm{CO}_{2}$ fixation, which has implications in the AOA-mediated coupling of $\mathrm{N}$ and $\mathrm{C}$ cycles in the environment and may contribute to the modeling of carbon and nitrogen cycles in AOA-dominated habitats.

\section{AUTHOR CONTRIBUTIONS}

Carlo Berg and Verona Vandieken initiated the enrichment cultures. Carlo Berg, Luisa Listmann and Klaus Jürgens designed the growth experiments. Carlo Berg and Luisa Listmann performed experiments and analysis. Angela Vogts performed measurements via NanoSIMS. Carlo Berg wrote the manuscript. Verona Vandieken, Angela Vogts, Luisa Listmann and Klaus Jürgens did proof-reading of the manuscript.

\section{ACKNOWLEDGMENTS}

This study was financed by the German Science Foundation (DFG) and European Science Foundation (EFG) within the EuroEEFG program and the project Microbial Oceanography of ChemolithoAutotrophic planktonic Communities (MOCA), grant JU 367/12-1. The SIMS instrument was funded by the German Federal Ministry of Education and Research (BMBF), grant identifier 03F0626A. Martin Könneke of MARUM is thanked for sharing his experience in enrichment procedures. Daniel P. R. Herlemann's useful help with ARB is highly appreciated. We thank Volkmar Senz, of the University of Rostock, for his assistance in preparing the gold-sputtered filters. The support of both the chief scientist of the $R / V$ Heincke, Martin Schmidt, and its crew and captain is highly appreciated. 


\section{SUPPLEMENTARY MATERIAL}

The Supplementary Material for this article can be found online at: http://www.frontiersin.org/journal/10.3389/fmicb. 2014.00786/abstract

\section{REFERENCES}

Alonso-Sáez, L., Waller, A. S., Mende, D. R., Bakker, K., Farnelid, H., Yager, P. L., et al. (2012). Role for urea in nitrification by polar marine Archaea. Proc. Natl. Acad. Sci. U.S.A. 109, 17989-17994. doi: 10.1073/pnas.1201914109

Amann, R. I., Binder, B. J., Olson, R. J., Chisholm, S. W., Devereux, R., and Stahl, D. A. (1990). Combination of 16S rRNA-targeted oligonucleotide probes with flow cytometry for analyzing mixed microbial populations. Appl. Environ. Microbiol. 56, 1919-1925.

Beman, J. M., Popp, B. N., and Francis, C. A. (2008). Molecular and biogeochemical evidence for ammonia oxidation by marine Crenarchaeota in the Gulf of California. ISME J. 2, 429-441. doi: 10.1038/ismej.2007.118

Berg, C., Vandieken, V., Thamdrup, B., and Jürgens, K. (2014). Significance of archaeal nitrification in hypoxic waters of the Baltic Sea. ISME J. doi: 10.1038/ismej.2014.218. [Epub ahead of print].

Berg, I. A., Kockelkorn, D., Buckel, W., and Fuchs, G. (2007). A 3hydroxypropionate/4-hydroxybutyrate autotrophic carbon dioxide assimilation pathway in Archaea. Science 318, 1782-1786. doi: 10.1126/science. 1149976

Biller, S. J., Mosier, A. C., Wells, G. F., and Francis, C. A. (2012). Global biodiversity of aquatic ammonia-oxidizing archaea is partitioned by habitat. Front. Microbiol. 3:252. doi: 10.3389/fmicb.2012.00252

Blainey, P. C., Mosier, A. C., Potanina, A., Francis, C. A., and Quake, S. R. (2011). Genome of a low-salinity ammonia-oxidizing archaeon determined by single-cell and metagenomic analysis. PLoS ONE 6:e16626. doi: 10.1371/journal.pone. 0016626

Bouskill, N. J., Eveillard, D., Chien, D., Jayakumar, A., and Ward, B. B. (2012). Environmental factors determining ammonia-oxidizing organism distribution and diversity in marine environments. Environ. Microbiol. 14, 714-729. doi: 10.1111/j.1462-2920.2011.02623.x

Brochier-Armanet, C., Boussau, B., Gribaldo, S., and Forterre, P. (2008). Mesophilic Crenarchaeota: proposal for a third archaeal phylum, the Thaumarchaeota. Nat. Rev. Microbiol. 6, 245-252. doi: 10.1038/nrmicro1852

Caffrey, J. M., Bano, N., Kalanetra, K., and Hollibaugh, J. T. (2007). Ammonia oxidation and ammonia-oxidizing bacteria and archaea from estuaries with differing histories of hypoxia. ISME J. 1, 660-662. doi: 10.1038/ismej.2007.79

Chain, P., Lamerdin, J., Larimer, F., Regala, W., Lao, V., Land, M., et al. (2003). Complete genome sequence of the ammonia-oxidizing bacterium and obligate chemolithoautotroph Nitrosomonas europaea. Society 185, 2759-2773. doi: 10.1128/JB.185.9.2759

Daims, H., Brühl, A., Amann, R., Schleifer, K. H., and Wagner, M. (1999). The domain-specific probe EUB338 is insufficient for the detection of all Bacteria: development and evaluation of a more comprehensive probe set. Syst. Appl. Microbiol. 22, 434-444. doi: 10.1016/S0723-2020(99)80053-8

DeLong, E. F. (1992). Archaea in coastal marine environments. Proc. Natl. Acad. Sci. U.S.A. 89, 5685-5689. doi: 10.1073/pnas.89.12.5685

Erguder, T. H., Boon, N., Wittebolle, L., Marzorati, M., and Verstraete, W. (2009). Environmental factors shaping the ecological niches of ammoniaoxidizing archaea. FEMS Microbiol. Rev. 33, 855-869. doi: 10.1111/j.15746976.2009.00179.x

Francis, C. A., Beman, J. M., and Kuypers, M. M. M. (2007). New processes and players in the nitrogen cycle: the microbial ecology of anaerobic and archaeal ammonia oxidation. ISME J. 1, 19-27. doi: 10.1038/ismej.2007.8

Francis, C. A., Roberts, K. J., Beman, J. M., Santoro, A. E., and Oakley, B. B. (2005). Ubiquity and diversity of ammonia-oxidizing archaea in water columns and sediments of the ocean. Proc. Natl. Acad. Sci. U.S.A. 102, 14683-14688. doi: 10.1073/pnas.0506625102

French, E., Kozlowski, J. A., Mukherjee, M., Bullerjahn, G., and Bollmann, A. (2012). Enrichment and characterization of three ammonia-oxidizing Archaea from freshwater environments. Appl. Environ. Microbiol. 78, 5773-5780. doi: 10.1128/AEM.00432-12

Glaubitz, S., Kießlich, K., Meeske, C., Labrenz, M., and Jürgens, K. (2013). SUP05 dominates the gammaproteobacterial sulfur oxidizer assemblages in pelagic redoxclines of the central Baltic and Black Seas. Appl. Environ. Microbiol. 79, 2767-2776. doi: 10.1128/AEM.03777-12
Grasshoff, K., Ehrhardt, M., and Kremling, K. (1983). Methods of Seawater Analysis. Weinheim: Verlag Chemie (VCH).

Grote, J., Jost, G., Labrenz, M., Herndl, G. J., and Jürgens, K. (2008). Epsilonproteobacteria represent the major portion of chemoautotrophic bacteria in sulfidic waters of pelagic redoxclines of the Baltic and Black Seas. Appl. Environ. Microbiol. 74, 7546-7551. doi: 10.1128/AEM.01186-08

Grote, J., Schott, T., Bruckner, C. G., Glöckner, F. O., Jost, G., Teeling, H., et al. (2012). Genome and physiology of a model Epsilonproteobacterium responsible for sulfide detoxification in marine oxygen depletion zones. Proc. Natl. Acad. Sci. U.S.A. 109, 506-510. doi: 10.1073/pnas.1111262109

Hallam, S. J., Konstantinidis, K. T., Putnam, N., Schleper, C., Watanabe, Y., Sugahara, J., et al. (2006a). Genomic analysis of the uncultivated marine crenarchaeote Cenarchaeum symbiosum. Proc. Natl. Acad. Sci. U.S.A. 103, 18296-18301. doi: 10.1073/pnas.0608549103

Hallam, S. J., Mincer, T. J., Schleper, C., Preston, C. M., Roberts, K., Richardson, P. M., et al. (2006b). Pathways of carbon assimilation and ammonia oxidation suggested by environmental genomic analyses of marine Crenarchaeota. PLoS Biol. 4:e95. doi: 10.1371/journal.pbio.0040095

Hammer, Ø., Harper, D. A. T., and Ryan, P. D. (2001). PAST: paleontological statistics software package for education and data analysis. Palaeontol. Electron. 4, 4. Available online at: http://palaeo-electronica.org/2001_1/past/ issue1_01.htm

Hatzenpichler, R. (2012). Diversity, physiology and niche differentiation of ammonia-oxidizing archaea. Appl. Environ. Microbiol. 78, 7501-7510. doi: 10.1128/AEM.01960-12

Hatzenpichler, R., Lebedeva, E. V., Spieck, E., Stoecker, K., Richter, A., Daims, H., et al. (2008). A moderately thermophilic ammonia-oxidizing crenarchaeote from a hot spring. Proc. Natl. Acad. Sci. U.S.A. 105, 2134-2139. doi: 10.1073/pnas.0708857105

Herndl, G. J., Reinthaler, T., Teira, E., van Aken, H., Veth, C., Pernthaler, A., et al. (2005). Contribution of archaea to total prokaryotic production in the deep atlantic ocean. Appl. Environ. Microbiol. 71, 2303-2309. doi: 10.1128/AEM.71.5.2303-2309.2005

Jansson, B. P., Malandrin, L., and Johansson, H. E. (2000). Cell cycle arrest in archaea by the hypusination inhibitor $N^{1}$-guanyl-1,7-diaminoheptane. J. Bacteriol. 182, 1158-1161. doi: 10.1128/JB.182.4.1158-1161.2000

Jung, M.-Y., Park, S.-J., Min, D., Kim, J.-S., Rijpstra, W. I. C., Sinninghe Damsté, J. S., et al. (2011). Enrichment and characterization of an autotrophic ammoniaoxidizing archaeon of mesophilic crenarchaeal group I.1a from an agricultural soil. Appl. Environ. Microbiol. 77, 8635-8647. doi: 10.1128/AEM.05787-11

Karner, M. B., DeLong, E. F., and Karl, D. M. (2001). Archaeal dominance in the mesopelagic zone of the Pacific Ocean. Nature 409, 507-510. doi: $10.1038 / 35054051$

Klotz, M. G., Arp, D. J., Chain, P. S. G., El-Sheikh, A. F., Hauser, L. J., Hommes, N. G., et al. (2006). Complete genome sequence of the marine, chemolithoautotrophic, ammonia-oxidizing bacterium Nitrosococcus oceani ATCC 19707. Appl. Environ. Microbiol. 72, 6299-6315. doi: 10.1128/AEM.00463-06

Könneke, M., Bernhard, A. E., de la Torre, J. R., Walker, C. B., Waterbury, J. B., and Stahl, D. A. (2005). Isolation of an autotrophic ammonia-oxidizing marine archaeon. Nature 437, 543-546. doi: 10.1038/nature03911

Könneke, M., Schubert, D. M., Brown, P. C., Hügler, M., Standfest, S., Schwander, T., et al. (2014). Ammonia-oxidizing archaea use the most energy-efficient aerobic pathway for $\mathrm{CO}_{2}$ fixation. Proc. Natl. Acad. Sci. U.S.A. 111, 8239-8244. doi: 10.1073/pnas.1402028111

Labrenz, M., Jost, G., and Jürgens, K. (2007). Distribution of abundant prokaryotic organisms in the water column of the central Baltic Sea with an oxic - anoxic interface. Aquat. Microb. Ecol. 46, 177-190. doi: 10.3354/ame046177

Labrenz, M., Sintes, E., Toetzke, F., Zumsteg, A., Herndl, G. J., Seidler, M., et al. (2010). Relevance of a crenarchaeotal subcluster related to Candidatus Nitrosopumilus maritimus to ammonia oxidation in the suboxic zone of the central Baltic Sea. ISME J. 4, 1496-1508. doi: 10.1038/ismej.2010.78

Lam, P., Lavik, G., Jensen, M. M., van de Vossenberg, J., Schmid, M., Woebken, D., et al. (2009). Revising the nitrogen cycle in the Peruvian oxygen minimum zone. Proc. Natl. Acad. Sci. U.S.A. 106, 4752-4757. doi: 10.1073/pnas.0812444106

Lane, D. J. (1991). "16S/23S rRNA sequencing," in Nucleic Acid Techniques in Bacterial Systematics, eds E. Stackebrandt and M. Goodfellow (Chichester: John Wiley \& Sons), 115-175.

Lebedeva, E. V., Hatzenpichler, R., Pelletier, E., Schuster, N., Hauzmayer, S., Bulaev, A., et al. (2013). Enrichment and genome sequence of the group 
I.1a ammonia-oxidizing archaeon " $\mathrm{Ca}$. Nitrosotenuis uzonensis" representing a clade globally distributed in thermal habitats. PLOS ONE 8:e80835. doi: 10.1371/journal.pone.0080835

Lee, S., and Fuhrman, J. A. (1987). Relationships between biovolume and biomass of naturally derived marine bacterioplankton. Appl. Environ. Microbiol. 53, 1298-1303.

Ludwig, W., Strunk, O., Westram, R., Richter, L., Meier, H., Yadhukumar, et al. (2004). ARB: a software environment for sequence data. Nucleic Acids Res. 32, 1363-1371. doi: 10.1093/nar/gkh293

Martens-Habbena, W., Berube, P. M., Urakawa, H., de la Torre, J. R., and Stahl, D. A. (2009). Ammonia oxidation kinetics determine niche separation of nitrifying Archaea and Bacteria. Nature 461, 976-979. doi: 10.1038/nature08465

Matsutani, N., Nakagawa, T., Nakamura, K., Takahashi, R., Yoshihara, K., and Tokuyama, T. (2011). Enrichment of a novel marine ammonia-oxidizing archaeon obtained from sand of an eelgrass zone. Microbes Environ. 26, 23-29. doi: 10.1264/jsme2.ME10156

Middelburg, J. J. (2011). Chemoautotrophy in the ocean. Geophys. Res. Lett. 38, 94-97. doi: 10.1029/2011GL049725

Mosier, A. C., Lund, M. B., and Francis, C. A. (2012). Ecophysiology of an ammonia-oxidizing archaeon adapted to low-salinity habitats. Microb. Ecol. 64, 955-963. doi: 10.1007/s00248-012-0075-1

Musat, N., Foster, R., Vagner, T., Adam, B. and Kuypers, M. M. M. (2012). Detecting metabolic activities in single cells, with emphasis on nanoSIMS. FEMS Microbiol. Rev. 36, 486-511. doi: 10.1111/j.1574-6976.2011.00303.x

Mußmann, M., Brito, I., Pitcher, A., Sinninghe Damste, J. S., Hatzenpichler, R., Richter, A., et al. (2011). Thaumarchaeotes abundant in refinery nitrifying sludges express amoA but are not obligate autotrophic ammonia oxidizers. Proc. Natl. Acad. Sci. U.S.A. 108, 16771-16776. doi: 10.1073/pnas.1106427108

Nier, A. O. (1950). A redetermination of the relative abundances of the isotopes of carbon, nitrogen, oxygen, argon and potassium. Phys. Rev. Lett. 77, 789-793. doi: 10.1103/PhysRev.77.789

Ouverney, C. C., and Fuhrman, J. A. (2000). Marine planktonic archaea take up amino acids. Appl. Environ. Microbiol. 66, 4829-4833. doi: 10.1128/AEM.66.11.4829-4833.2000

Pernthaler, A., Pernthaler, J., and Amann, R. (2002). Fluorescence in situ hybridization and catalyzed reporter deposition for the identification of marine bacteria. Appl. Environ. Microbiol. 68, 3094-3101. doi: 10.1128/AEM.68.6.30943101.2002

Pester, M., Rattei, T., Flechl, S., Gröngröft, A., Richter, A., Overmann, J., et al. (2012). amoA-based consensus phylogeny of ammonia-oxidizing archaea and deep sequencing of amoA genes from soils of four different geographic regions. Environ. Microbiol. 14, 525-539. doi: 10.1111/j.1462-2920.2011.02666.x

Polerecky, L., Adam, B., Milucka, J., Musat, N., Vagner, T., and Kuypers, M. M. M. (2012). Look@NanoSIMS - a tool for the analysis of nanoSIMS data in environmental microbiology. Environ. Microbiol. 14, 1009-1023. doi: 10.1111/j.14622920.2011.02681.x

Pruesse, E., Peplies, J., and Glöckner, F. O. (2012). SINA: accurate high-throughput multiple sequence alignment of ribosomal RNA genes. Bioinformatics 28, 1823-1829. doi: 10.1093/bioinformatics/bts252

Purkhold, U., Pommerening-Röser, A., Juretschko, S., Schmid, M. C., Koops, H. P., and Wagner, M. (2000). Phylogeny of all recognized species of ammonia oxidizers based on comparative 16S rRNA and amoA sequence analysis: implications for molecular diversity surveys. Appl. Environ. Microbiol. 66, 5368-5382. doi: 10.1128/AEM.66.12.5368-5382.2000

Qin, W., Amin, S. A., Martens-Habbena, W., Walker, C. B., Urakawa, H., Devol, A. H., et al. (2014). Marine ammonia-oxidizing archaeal isolates display obligate mixotrophy and wide ecotypic variation. Proc. Natl. Acad. Sci. U.S.A. 111, 12504-12509. doi: 10.1073/pnas.1324115111

Quast, C., Pruesse, E., Yilmaz, P., Gerken, J., Schweer, T., Yarza, P., et al. (2013). The SILVA ribosomal RNA gene database project: improved data processing and web-based tools. Nucleic Acids Res. 41, D590-D596. doi: 10.1093/nar/gks1219

Santoro, A. E., and Casciotti, K. L. (2011). Enrichment and characterization of ammonia-oxidizing archaea from the open ocean: phylogeny, physiology and stable isotope fractionation. ISME J. 5, 1796-1808. doi: 10.1038/ismej.2011.58

Spang, A., Hatzenpichler, R., Brochier-Armanet, C., Rattei, T., Tischler, P., Spieck, E., et al. (2010). Distinct gene set in two different lineages of ammonia-oxidizing archaea supports the phylum Thaumarchaeota. Trends Microbiol. 18, 331-340. doi: 10.1016/j.tim.2010.06.003
Spang, A., Poehlein, A., Offre, P., Zumbrägel, S., Haider, S., Rychlik, N., et al. (2012). The genome of the ammonia-oxidizing Candidatus Nitrososphaera gargensis: insights into metabolic versatility and environmental adaptations. Environ. Microbiol. 14, 3122-3145. doi: 10.1111/j.1462-2920.2012.02893.x

Stahl, D., A., and Amann, R. (1991). "Development and application of nucleic acid probes in bacterial systematics," in Nucleic Acid Techniques in Bacterial Systematics, eds M. Stackebrandt, E., Goodfellow (Chichester, UK: John Wiley and Sons), 205-248.

Stieglmeier, M., Klingl, A., Alves, R. J. E., Rittmann, S. K.-M. R., Melcher, M., Leisch, N., et al. (2014). Nitrososphaera viennensis sp. nov., an aerobic and mesophilic ammonia-oxidizing archaeon from soil and member of the archaeal phylum Thaumarchaeota. Int. J. Syst. Evol. Microbiol. 007536, 2738-2752. doi: 10.1099/ijs.0.063172-0

Teira, E., Burg, D., van Aken, H., Veth, C., and Herndl, G. J. (2006). Archaeal uptake of enantiomeric amino acids in the meso- and bathypelagic waters of the North Atlantic. Limnol. Oceanogr. 51, 60-69. doi: 10.4319/lo.2006.51.1.0060

Tijhuis, L., Van Loosdrecht, M. C., and Heijnen, J. J. (1993). A thermodynamically based correlation for maintenance gibbs energy requirements in aerobic and anaerobic chemotrophic growth. Biotechnol. Bioeng. 42, 509-519. doi: 10.1002/bit.260420415

Tourna, M., Stieglmeier, M., Spang, A., Könneke, M., Schintlmeister, A., and Urich, T. (2011). Nitrososphaera viennensis, an ammonia oxidizing archaeon from soil. Proc. Natl. Acad. Sci. U.S.A. 108, 8420-8425. doi: 10.1073/pnas.10134 88108

Treusch, A. H., Leininger, S., Kletzin, A., Schuster, S. C., Klenk, H.-P., and Schleper, C. (2005). Novel genes for nitrite reductase and Amo-related proteins indicate a role of uncultivated mesophilic crenarchaeota in nitrogen cycling. Environ. Microbiol. 7, 1985-1995. doi: 10.1111/j.1462-2920.2005.00906.x

Varela, M. M., van Aken, H. M., Sintes, E., Reinthaler, T., and Herndl, G. J. (2011). Contribution of crenarchaeota and bacteria to autotrophy in the North Atlantic interior. Environ. Microbiol. 13, 1524-1533. doi: 10.1111/j.14622920.2011.02457.x

Venter, J. C., Remington, K., Heidelberg, J. F., Halpern, A. L., Rusch, D., Eisen, J. A., et al. (2004). Environmental genome shotgun sequencing of the Sargasso Sea. Science 304, 66-74. doi: 10.1126/science.1093857

Walker, C. B., de la Torre, J. R., Klotz, M. G., Urakawa, H., Pinel, N., Arp, D. J., et al. (2010). Nitrosopumilus maritimus genome reveals unique mechanisms for nitrification and autotrophy in globally distributed marine crenarchaea. Proc. Natl. Acad. Sci. U.S.A. 107, 8818-8123. doi: 10.1073/pnas.0913533107

Weinbauer, M. G., Fritz, I., Wenderoth, D. F., and Höfle, M. G. (2002). Simultaneous extraction from bacterioplankton of total RNA and DNA suitable for quantitative structure and function analyses. Appl. Environ. Microbiol. 68, 1082-1087. doi: 10.1128/AEM.68.3.1082-1087.2002

Wright, E. S., Yilmaz, L. S., and Noguera, D. R. (2012). DECIPHER, a search-based approach to chimera identification for $16 \mathrm{~S}$ rRNA sequences. Appl. Environ. Microbiol. 78, 717-725. doi: 10.1128/AEM.06516-11

Wuchter, C., Abbas, B., Coolen, M. J. L., Herfort, L., van Bleijswijk, J., Timmers, P., et al. (2006). Archaeal nitrification in the ocean. Proc. Natl. Acad. Sci. U.S.A. 103, 12317-12322. doi: 10.1073/pnas.0600756103

Conflict of Interest Statement: The authors declare that the research was conducted in the absence of any commercial or financial relationships that could be construed as a potential conflict of interest.

Received: 01 October 2014; accepted: 21 December 2014; published online: 15 January 2015.

Citation: Berg C, Listmann L, Vandieken V, Vogts A and Jürgens K (2015) Chemoautotrophic growth of ammonia-oxidizing Thaumarchaeota enriched from a pelagic redox gradient in the Baltic Sea. Front. Microbiol. 5:786. doi: 10.3389/fmicb. 2014.00786

This article was submitted to Aquatic Microbiology, a section of the journal Frontiers in Microbiology.

Copyright (c) 2015 Berg, Listmann, Vandieken, Vogts and Jürgens. This is an openaccess article distributed under the terms of the Creative Commons Attribution License (CC BY). The use, distribution or reproduction in other forums is permitted, provided the original author(s) or licensor are credited and that the original publication in this journal is cited, in accordance with accepted academic practice. No use, distribution or reproduction is permitted which does not comply with these terms. 